\title{
Al-Au-Cu (Aluminum-Gold-Copper)
}

\author{
V. Raghavan
}

An update of the experimental results of [2002Lev] and [2003Lev] on this ternary system was presented by [2008Rag]. Recently, [2010Bha] determined an isothermal section at $750{ }^{\circ} \mathrm{C}$ and $[2009 \mathrm{Gu}]$ studied the $A 2 \leftrightarrow B 2 \leftrightarrow L 1_{2}$ ordering transitions.

\section{Binary Systems}

The Al-Au system [2005Oka] depicts the following intermediate phases: $\mathrm{AuAl}_{2}\left(\mathrm{Cl}, \mathrm{CaF}_{2}\right.$-type cubic $), \mathrm{AuAl}$ (AuAl-type monclinic), $\mathrm{Au}_{2} \mathrm{Al}(\alpha, \beta$, and $\gamma$ modifications with $\mathrm{MoSi}_{2}$-type or related structures), $\mathrm{Au}_{8} \mathrm{Al}_{3}$ (rhombohedral, space group $R \overline{3} c$ ), $\mathrm{Au}_{4} \mathrm{Al}$ (cubic, space group $P 2{ }_{1} 3$ ), and $\beta(80-81.2$ at.\% $\mathrm{Au} ; \mathrm{bcc})$. The $\mathrm{Al}-\mathrm{Cu}$ phase diagram [2004Ria] depicts a number of intermediate phases: $\mathrm{CuAl}_{2}$ ( $\theta, C 16$-type tetragonal), $\mathrm{CuAl}(\mathrm{HT})\left(\eta_{1}\right.$, orthorhombic), $\mathrm{CuAl}(\mathrm{LT})\left(\eta_{2}\right.$, monoclinic), $\mathrm{Cu}_{5} \mathrm{Al}_{4}(\mathrm{HT})\left(\zeta_{1}\right.$, orthorhombic, space group Fmm2), $\mathrm{Cu}_{5} \mathrm{Al}_{4}$ (LT) ( $\zeta_{2}$, orthorhombic, space group Imm 2$), \varepsilon_{1}(\mathrm{HT})$ (bcc), $\varepsilon_{2}(\mathrm{LT})\left(B 8_{2}, \mathrm{Ni}_{2}\right.$ In-type hexagonal), $\mathrm{Cu}_{3} \mathrm{Al}_{2}$ ( $\delta$, rhombohedral), $\mathrm{Cu}_{9} \mathrm{Al}_{4}(\mathrm{HT})\left(\gamma_{0}, D 8_{2}\right.$, $\mathrm{Cu}_{5} \mathrm{Zn}_{8}$-type cubic), $\mathrm{Cu}_{9} \mathrm{Al}_{4}(\mathrm{LT})\left(\gamma_{1}, \mathrm{D}_{3}\right.$-type cubic), and $\mathrm{Cu}_{3} \mathrm{Al}(\beta, \mathrm{bcc})$. In the above, $\mathrm{HT}=$ high-temperature and $\mathrm{LT}=$ low-temperature. $\mathrm{Au}$ and $\mathrm{Cu}$ form a continuous face-centered cubic (fcc) solid solution at high temperatures. At lower temperatures, at least three ordered structures $\mathrm{Au}_{3} \mathrm{Cu}$ $\left(L 1_{2}, \mathrm{AuCu}_{3}\right.$-type cubic), AuCu-I ( $L 1_{0}$, AuCu-type tetragonal) and $\mathrm{AuCu}_{3}-\mathrm{I}\left(L 1_{2}\right.$-type cubic) are known, with formation temperatures of 240,385 and $390{ }^{\circ} \mathrm{C}$ respectively [Massalski2].

\section{Ternary Phase Equilibria}

With starting metals of $99.99+\% \mathrm{Al}, 99.99 \% \mathrm{Au}$ and $99.9 \% \mathrm{Cu}$, [2010Bha] melted 14 ternary alloys in an alumina crucible under a protective layer of carbon pellets. The alloys were annealed at $750{ }^{\circ} \mathrm{C}$ and quenched in iced brine. The phase equilibria were studied with optical and scanning electron microscopy, energy dispersive spectroscopy and x-ray powder diffraction. Differential scanning calorimetry was performed at a heating rate of $10^{\circ} \mathrm{C} / \mathrm{min}$. The isothermal section at $750{ }^{\circ} \mathrm{C}$ constructed by [2010Bha] is shown in Fig. 1. The $\mathrm{Cu}_{3} \mathrm{Al}(\beta)$ bcc phase extends deep into the ternary region, dissolving more than 43 at. $\% \mathrm{Au}$. At $500{ }^{\circ} \mathrm{C}, \mathrm{Cu}_{3} \mathrm{Al}$ is not stable in the $\mathrm{Al}-\mathrm{Cu}$ binary system. At this temperature, this phase appears within the ternary region [2002Lev]. The $\mathrm{Cu}_{9} \mathrm{Al}_{4}\left(\gamma_{1}\right)$ phase also extends up to $\sim 40$ at.\% $\mathrm{Au}$, with $\mathrm{Au}$ substituting for $\mathrm{Cu}$. A large liquid field, originating from the $\mathrm{Al}-\mathrm{Au}$ side, extends into the ternary region. Based on their experimental data, [2010Bha] suggested a correction to the slope of the $\beta /\left(\beta+\gamma_{1}\right)$ phase

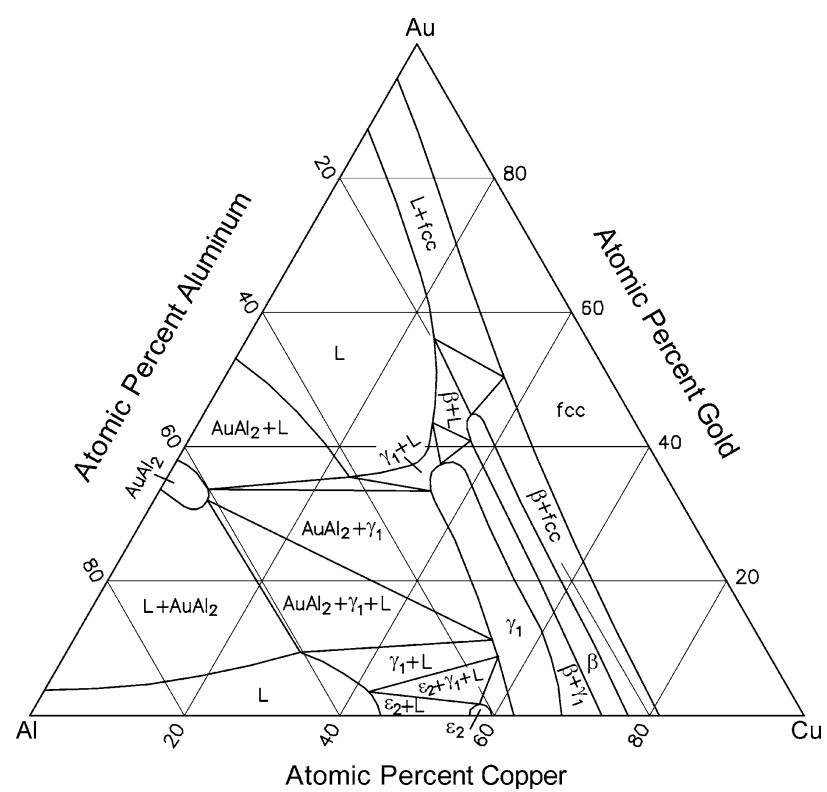

Fig. 1 Al-Au-Cu isothermal section at $750{ }^{\circ} \mathrm{C}$ [2010Bha]

boundary in the vertical section at $\sim 76$ mass $\%$ Au reported by [2003Lev].

Employing electrical resistivity and internal friction measurements, $[2009 \mathrm{Gu}]$ determined the critical transition temperatures in the $A 2 \rightarrow B 2$ and $B 2 \rightarrow L 2_{1}$ ordering in $(\mathrm{Cu}, \mathrm{Au})_{3} \mathrm{Al}$ bcc alloys. The measured temperatures showed good agreement with those calculated from the BraggWilliams-Gorski model.

\section{References}

2002Lev: F.C. Levey, M.B. Cortie, and L.A. Cornish, A $500{ }^{\circ} \mathrm{C}$ Isothermal Section for the $\mathrm{Al}-\mathrm{Au}-\mathrm{Cu}$ System, Metall. Mater. Trans. A, 2002, 33A, p 987-993

2003Lev: F.C. Levey, M.B. Cortie, and L.A. Cornish, Determination of the 76 Mass Percent Au Section of the Al-Au-Cu Phase Diagram, J. Alloys Compd., 2003, 354, p 171-180

2004Ria: P. Riani, L. Arrighi, R. Marazza, D. Mazzone, G. Zanicchi, and R. Ferro, Ternary Rare-Earth Aluminum Systems with Copper: A Review and a Contribution to Their Assessment, J. Phase Equilib. Diffus., 2004, 25(1), p 22-52

2005Oka: H. Okamoto, Al-Au (Aluminum-Gold), J. Phase Equilib. Diffus., 2005, 26(4), p 391-393

2008Rag: V. Raghavan, $\mathrm{Al}-\mathrm{Au}-\mathrm{Cu}$ (Aluminum-Gold-Copper), J. Phase Equilib. Diffus., 2008, 29(3), p 260-261

2009Gu: Y. Gu, M. Jin, and X. Jin, $A 2 \rightarrow B 2 \rightarrow L 1_{2}$ Ordering Transitions in Au-Cu-Al Alloys, Intermetallics, 2009, 17, p 704707

2010Bha: V.K. Bhatia, C.S. Kealley, R. Wuhrer, K.S. Wallwork, and M.B. Cortie, Ternary $\beta$ and $\gamma$ phases in the Al-Au-Cu System at $750{ }^{\circ} \mathrm{C}$, J. Alloys Compd., 2010, 488, p 100-107 